\title{
Searching for the "Inner Light": The Development of Henry A. Wallace's Experimental Spiritualism
}

\author{
MARK L. KLEINMAN
}

HENRY A. WALLACE was for a time in the twentieth century Iowa's favorite son. Yet he is usually remembered for his greatest failure: resounding defeat as a third-party candidate on the Progressive Party ticket for the presidency in 1948. He deserves a better fate. In the years predating his government service, Wallace was both a preeminent agricultural scientist and a prominent midwestern agrarian leader as editor of his family's Iowa-based farm journal, Wallaces' Farmer. During the Great Depression, as Franklin D. Roosevelt's secretary of agriculture, Wallace was more closely associated in the public consciousness with the New Deal than perhaps anyone save Roosevelt himself. And Wallace's crusade for a "Century of the Common Man," undertaken as vice-president during the Second World War, made him the outstanding American champion of cooperative postwar international relations.

Despite his personal successes and public contributions, Wallace often has been recalled in rather derogatory terms, especially as some sort of a "fuzzy-minded" mystic. ${ }^{1}$ Widespread

1. The term was used by Dwight MacDonald in his short and rather vicious 1947 book, Henry Wallace: The Man and the Myth (New York, 1947), 181. Elaborating on this theme, MacDonald also characterized Wallace as a "cornfed mystic" possessed of a "constitutional fuzziness of judgment" $(116,20)$. In what was essentially a political tract, MacDonald relied heavily on quotation out of context and on recounting only portions of anecdotes to create his

THE ANNALS OF IOWA 53 (Summer 1994). OThe State Historical Society of Iowa, 1994. 
assertions during the 1948 presidential campaign characterized Wallace as a starry-eyed dupe of the Communist Party. The image was augmented by the general cultural climate of the Cold War era. Such assessments of Wallace's personality helped undermine the credibility of the policies he advocated.

By the late 1960s and 1970s, in the context of wide-ranging criticisms of American society and culture, evaluations of Wallace greatly improved. Various writers noted his contributions to American political culture and in some cases even insisted that Wallace had been ahead of his time as a political thinker. ${ }^{2}$ In these later works, however, the question of Wallace's spiritualism, so damning in the minds of earlier critics, was either sidestepped or not explored to its fullness, thus rendering even these more favorable treatments incomplete. ${ }^{3}$

portrait of Wallace. Borrowing from right-wing columnist Westbrook Pegler, historian Arthur Schlesinger Jr., in his multivolume history of the Great Depression and the New Deal, The Age of Roosevelt, vol. 2, The Coming of the New Deal (Boston, 1959), 33, treated Wallace with similar disdain, terming him a "spiritual window shopper."

2. Richard Walton's Henry Wallace; Harry Truman, and the Cold War (New York, 1976) is an example of this interpretation.

3. The first volume of Edward L. and Frederick H. Schapsmeier's biography of Wallace, Henry A. Wallace of Iowa: The Agrarian Years, 1910-1940 (Ames, 1968), is an example of sidestepping the issue of Wallace's spiritualism. Only twice in the entire book do they specifically (and briefly) mention Wallace's non-mainstream spiritual propensities, once noting that he "delved into theosophy and oriental beliefs" (137) and once asserting that he always demonstrated a willingness to "investigate spiritual phenomena" (274). Norman D. Markowitz, in The Rise and Fall of the People's Century: Henry A. Wallace and American Liberalism, 1941-1948 (New York, 1973), clearly sensed the influence of Wallace's spiritualism on his social and political philosophy, yet Markowitz limited his discussion primarily to an illuminating appendix (333-42) on Wallace's connection with the emigré Russian mystic, Nicholas Roerich. Markowitz did not address the wider range of Wallace's spiritual relationships, probably because they predated the chronological focus of his study. In an article that focused on Wallace's relationship with Roerich, Charles Errico and J. Samuel Walker, "The New Deal and the Guru," American Heritage 40 (March 1989), 93, briefly alluded to the greater extent of Wallace's "quest for spiritual satisfaction." But since their intent was to bring the somewhat sensational story of Wallace and Roerich to the popular press, they did not go into any detail regarding Wallace's other spiritual relationships. Stow Persons did suggest briefly that Wallace's "religious migration" was "not without lasting effects on his thinking about public matters." See Persons, "Comment" on Richard S. Kirkendall's "The Mind of a Farm Leader," Annals of Iowa 47 (1983), 158. 
Attempting to understand Wallace's career without grasping the nature and extent of his spiritualism is to perform something of a historical lobotomy. It denies Wallace a part of his personality and deprives his ideology of one of its essential components.

Wallace's turn to politics in the 1930s and 1940s to remedy the ills of American society is well documented, as is his lifelong commitment to agricultural science. Yet despite widespread speculation about his spiritual eccentricities, there exists no thorough study of his actual spiritual pursuits in the years before he entered political life. The object of this article is to show that Wallace's spiritual quest during the 1920s and 1930s formed an essential part of his complete philosophical outlook, and that, in an age that increasingly separated science and religion, his spiritualism complemented his scientific experimentalism.

WALLACE inherited a background in agricultural science. His grandfather, "Uncle Henry," left the Presbyterian ministry to begin his agricultural career in 1877 . He quickly proved adept at "scientific farming," making use of "all the latest techniques of husbandry." Uncle Henry's son, Henry C. Wallace (Henry A.'s father), carried this interest in experimental farming further, for a short time as a professor of agriculture at Iowa State College in Ames. ${ }^{4}$ Thus it is not surprising that one of Henry A.'s careers was in agricultural science, specifically corn genetics.

Probing the mysteries of agricultural breeding in both plants and animals remained Wallace's great passion throughout his life. During the 1920s and early 1930s in particular, Wallace engaged in agricultural experimentation in areas ranging from innovative methods of corn cultivation to the care and breeding of hogs and poultry. Had Wallace devoted his life exclusively to these endeavors - especially to genetics - his contributions, important as they were, would have been vast. ${ }^{5}$

Wallace also studied weather and natural phenomena prediction, an arena of experimentation pertinent to agriculture. Throughout the 1920s and early 1930s he tracked the results of

4. Russell Lord, The Wallaces of Iowa (Boston, 1947), 2-5; Schapsmeier and Schapsmeier, Henry A. Wallace, 5-6, 9, 17-20.

5. Schapsmeier and Schapsmeier, Henry A. Wallace, 16-29. 
a wide range of research. For example, he supported experiments in long-range weather forecasting based on correlation of changes in solar radiation with ocean temperatures, even though such research was at that time regarded skeptically. He also followed research on the influence of the moon's phases on crop planting. ${ }^{7}$ On his own, Wallace studied patterns of planetary alignments, terrestrial magnetism, earthquakes, and volcanic eruptions. He believed that all or some of these phenomena may have been connected to terrestrial weather. ${ }^{8}$ During the early 1930s Wallace wrote editorial weather columns in Wallaces' Farmer based on his research on the relationship between the earth's weather and the positions of the other planets of the solar system. ${ }^{9}$ Ultimately, he combined his meteorological and natural phenomenological studies with an interest in statistics by using the new and still fairly primitive "punch card" technology to collate his large mass of planetary data. ${ }^{10}$

6. Wallaces' Farmer, 2 January 1925, 5; Henry A. Wallace (hereafter cited as HAW) to Herbert Janvrin Browne, 5 March 1925, Henry Agard Wallace Papers, Special Collections, University of Iowa Libraries, Iowa City. See also Browne to HAW, 2 March 1925, and HAW to Browne, 11 March 1929, Wallace Papers; Wallaces' Farmer, 4 September 1925, 1125.

7. See Wallaces' Farmer, 13 June 1924, 866, in which Wallace applauded the efforts of D. W. May, who was at an experiment station in Puerto Rico testing the widespread local belief in planting by the phases of the moon. Although Wallace acknowledged that the experiments demonstrated no lunar influence whatsoever, he asserted all the same that he admired "Mr. May's spirit in experimenting with things no matter how absurd they may seem."

8. For Wallace's voluminous compilations of planetary alignments, see HAW to Dr. W. Gray Moseley, 7 July 1930, Wallace Papers. For his efforts regarding other phenomena, see HAW to Rev. John Jones Smith, 12 January, 18 January, 14 February, 27 April 1929, 5 April 1930; and HAW to William I. Rooney, 27 February 1930, Wallace Papers. Smith edited The National Weather Book, an almanac published in St. Louis. Wallace wrote to him requesting data on diverse natural phenomena. HAW to O.S. Bowman, 8 February 1929; Smith to HAW, 14 January 1929, Wallace Papers.

9. See Wallaces' Farmer, 8 March 1930, 470; 26 April 1930, 830, 831; 3 January 1931, 6; and HAW to Mrs. Frank Briggs, 5 January 1931, Wallace Papers.

10. Wallace described his punch card system to Dr. Ellsworth Huntington of the Department of Geological Sciences, Yale University. HAW to Huntington, 10 June 1930, Wallace Papers. See also Huntington to HAW, 7 October 1930; HAW to Huntington, 13 October 1930; HAW to Dr. Benjamin Boss (Dudley Observatory), 23 September 1930; HAW to Professor Lincoln W. Hall (Wharton School), 31 October 1930, Wallace Papers; Schapsmeier and Schapsmeier, Henry A. Wallace, 26. 
Wallace's scientific experimentalism included wide-ranging correspondence with those who shared his interests. By the late 1920s, that correspondence extended throughout the world, contributing to Wallace's growing awareness of international interdependence.

Wallace's political career eventually pulled him away from science, yet his interest in scientific matters never waned. Throughout his years in Washington, D.C., Wallace remained abreast of various science-oriented issues and was viewed by some as a scientist in public office. Physicist Vannevar Bush, for example, believed Wallace was the only member of the Roosevelt and Truman administrations capable of fathoming the scientific intricacies of atomic energy. ${ }^{11}$

Understanding Wallace as a scientist helps explain his penchant for applying his conception of the scientific methodessentially a disciplined open-mindedness - to a whole range of issues outside of science. He was willing to examine any theory of knowledge, including those others might view as eccentric. Wallace recalled that in corn hybridization he would not reject any samples out of hand because he had often seen apparently poor corn samples produce viable offspring. The only way to know what the corn was worth was to crossbreed it and see what resulted. As with corn, so it was with other intellectual pursuits: Wallace refused to reject any creed or hypothesis a priori. No matter how superficially repugnant a particular proposition's conceptual basis might seem to some, Wallace treated it as worthy of consideration until examination and trial proved otherwise.

WALLACE'S EXPERIMENTALISM informed his profound curiosity about the spiritual world. His spiritualism was in part a legacy from his grandfather, who had gone to Iowa from Pennsylvania in the 1860 s as a progressive minister in the United Presbyterian Church. Although he left the ministry to take up farming and journalism, Uncle Henry's religious beliefs,

11. Markowitz, People's Century, 174. See also entry for 4 December 1943 in Diary of Henry A. Wallace, January 18, 1935-September 19, 1946, Special Collections, University of Iowa Libraries, Iowa City. 
grounded in social reform themes similar to those that would make up the Social Gospel, continued to exert a profound influence in his life. Because of an extraordinary closeness between grandfather and grandson, those beliefs had a similar effect on the younger Wallace. ${ }^{12}$

Yet even here Henry A.'s proclivity toward the mystical was apparent. As a young man he had rejected what he characterized as the "severely logical" sermons of the Presbyterians and temporarily adopted an attitude of scientific skepticism. Eventually, however, the "spiritual beauty" of the Mass drew him back to Christianity, specifically the Episcopal Church. ${ }^{13}$ By the late 1920s, Wallace's religious propensity led him to examine diverse belief systems, including Hinduism, Bahaism, astrology, and American Indian religions. With the support of several individuals who shared his spiritual propensity, Wallace intertwined his science and his spiritual studies into a distinctive "experimental spiritualism."14

Wallace was most captivated during the 1920 s and early 1930s by the "wisdom religion" of Theosophy, a religious system eminently suited to Wallace's philosophical intertwining of science and spiritualism. ${ }^{15}$ The Theosophical Society itself was created in New York in 1875. Led by a charismatic and controversial Russian emigré, Helena P. Blavatsky, and a spiritually inclined American lawyer, Colonel Henry Olcott, the society attracted predominantly "solidly middle-class," mostly

12. On the extraordinary closeness between Uncle Henry and his grandson, Henry A. Wallace, as well as the impact it had on the latter's intellectual growth, see Schapsmeier and Schapsmeier, Henry A. Wallace, 2, 17-18; and Lord, The Wallaces of Iowa, 10-12.

13. Henry A. Wallace, Statesmanship and Religion (London, 1934), 45-47.

14. For a full discussion of the nature and extent of Wallace's spiritualism during these years, see Mark L. Kleinman, "Approaching Opposition: Henry A. Wallace, Reinhold Niebuhr, and the Emergence of American Liberal Internationalism, 1920-1942" (Ph.D. diss., UCLA, 1991), ch. 2.

15. The term wisdom religion is taken from a prominent Theosophist, William Quan Judge, with whose writings Wallace was familiar. See William Quan Judge, Echoes from the Orient: A Broad Outline of Theosophical Doctrines (Point Loma, CA, 1921); and Sven Eek and Boris de Zirkoff, comps., William Quan Judge, 1851-1896: The Life of a Theosophical Pioneer and Some of His Outstanding Articles (Wheaton, IL, 1969). 
professional people who were "active in nontraditional forms of religion and spirituality." The organization grew fairly quickly to international proportions, ultimately developing many offshoots and experiencing several schisms. ${ }^{16}$

In general, the movement's leaders claimed that Theosophy transcended the "cleavage between science and religion" by returning to an "ancient wisdom-tradition" of the Far East. Theosophists asserted that supernatural revelation imparted to spiritually sensitive individuals by semi-divine beings could inform rational, deductive reasoning about the nature of the physical world. Revealing the influence of various east Indian religious traditions, Theosophists called these near-divinities "Masters" or "Mahatmas." Also derived from eastern spiritualism was Theosophy's acknowledgment of the existence of an eternal process of reincarnation, driven by the principle of "karma."17

Wallace first approached Theosophy through the Liberal Catholic Church, one of the main schismatic offshoots of the original Theosophical Society. The Los Angeles-based sect was established in 1917 by Charles W. Leadbeater, a former Anglican curate. The variations on Anglican-Catholic ritual that he brought to Theosophy gave it greater credibility among Christians like Wallace. As early as 1925 Wallace established contact with the church. Eventually he was offered ordination in the group, which he turned down due to "domestic affairs." $\mathrm{He}$ did, however, accept appointment as secretary of the church's Des Moines mission and was listed as such in the church's directory. ${ }^{18}$

16. Bruce F. Campbell, Ancient Wisdom Revived: A History of the Theosophical Movement (Berkeley, CA, 1980), 27.

17. Ibid., 29. See also Judge, Echoes from the Orient, 1, 16-19.

18. Campbell, Ancient Wisdom, 125-27; HAW to Liberal Catholic Church, 30 August 1925; Bishop Irving S. Cooper to HAW, 12 July 1927; Directory, Liberal Catholic Churches and Missions, November 1928, Wallace Papers. Along with these documents, the Wallace Papers (supplementary boxes 61 and 63) contain various publications of the Liberal Catholic Church, as well as numerous confirmation and baptismal certificates of Des Moines church members that were probably in Wallace's possession as secretary of the mission. There is no evidence that Wallace maintained any relationship with the church after 1929. 
Another of Wallace's early Theosophical associations was with George W. "AE" Russell, whom he first met in 1912 and became reacquainted with in 1930. Russell was an Irish poet and mystic, a central figure in the Irish literary renaissance of the late nineteenth century, which itself was strongly influenced by Theosophy. In the late 1880 s a common interest in mysticism and Theosophy brought Russell together with other contributors to the Irish renaissance, such as William Butler Yeats, Charles Johnston, John Eglinton, and Charles Weekes. By the time Wallace met him, Russell had spent years studying religion, mysticism, and Theosophy. His writings were heavily laden with his sense of a supernatural realm that one could connect with only outside the city, only by getting back to the land, to the primitive earth. Foreshadowing a strain of environmental philosophy that would develop later in the century, Russell wrote of the earth as a living, breathing being. After his mystic "awakening" to this awareness, he said, the earth "began more and more to bewitch me, and to lure me to her heart with honied entreaty."19

This fundamental idea, that a return to the earth as a spiritual fountainhead could lead to a new era of human existence, supported the other major facet of Russell's life: his activities as a leader in the Irish agricultural cooperative movement. His cooperative philosophy and his endeavors to implement it paralleled Wallace's own strong advocacy of cooperation and heightened Wallace's interest in Russell's land-oriented spiritualism. Impressed at the time by what he viewed as Russell's "practical" mysticism, Wallace sensed that Russell seemed to be "really living in another world," yet clearly desired to "have that other world come true in this world." Wallace lamented his own lack of Russell's apparent degree of "facility of mental movement in the spiritual world," yet, in defending Russell's spiritual abilities to a close but skeptical friend, he implied that he himself had had some psychic experiences. Manifesting his experimentalist demeanor, Wallace insisted that "it is a mistake for scientific and the common sense

19. Campbell, Ancient Wisdom, 166-67; George W. Russell, The Candle of Vision (London, 1920), 10-11. 
people to shut the door to some of these things which they cannot understand. ${ }^{\prime 20}$

BY THE EARLY 1930s, Wallace's attraction to George Russell's spiritualism and to Theosophy led to his involvement in a loose network of spiritualists. For Wallace, the primary focus of this fellowship was Charles Roos, a poet and lyricist as well as an aficionado of Native American culture. From childhood Roos had lived with "Indians, woodsmen, [and] hunters" and worked as a miner, a cowboy, and a woodsman. He was clearly at home in the outdoors. In the 1930s and 1940s Roos and his wife, Juanita - also a lyricist and a newspaper editor - served as U.S. government inspectors for all Indian reservations west of Michigan. Their lyrical and poetic work focused largely on nature, the wilderness, and Native American life and knowledge. ${ }^{21}$

Wallace's frequent and enthusiastic letters to Charles Roos indicate that he enjoyed Roos and was interested in his spiritual knowledge. Wallace asked Roos, for example, about the interpretation of various Native American symbols he came across in his correspondence with other individuals. Eventually, Wallace even had Charles and Juanita conducting corn-growing experiments on land he had purchased near their home in Taylors Falls, Minnesota. ${ }^{22}$

This juxtaposition of Native American spiritualism and corn experimentation points up a crucial feature of Wallace's relationship with Roos and with the other individuals connected to their friendship. Roos's spirituality, grounded in Native American religion, was, like Russell's, based on an affinity for the land,

20. Wallaces' Farmer, 6 September 1930, 1419; HAW to G. W. Russell, 22 December 1930; HAW to Mark Hyde, 14 July 1930, Wallace Papers. See also Wallace to Hyde, 24 December 1930, Wallace Papers.

21. "In the Foreground: Tradition Rich Author of Northern Ways," Swedish Tribune-News, 11 January 1922, translated by Even L. Moberg, 2 September 1953; "Juanita Roos: Author-Composer" (no journal title or date [circa 1945]); "Indian Policies Look Far Ahead" (no journal title or date [circa early 1930s]), Johan Oscar Roos (1827-1896) and Family Papers, Minnesota Historical Society.

22. See, for example, HAW to Roos, 24 November 1931; Juanita Roos to HAW, [October 1931?]; and Charles Roos to HAW, 10 November 1931, Wallace Papers. 
for nature, for the earth itself. As Wallace put it, "Charley .. . laid particular emphasis on the necessity for the American religion finding its roots in our own earth." To Wallace, this seemed similar to George Russell's assertion that the absence of a "mystical feeling about the American soil" was the "great lack" in American culture. Russell allowed that "Emerson, Whitman and Thoreau had that dirt feeling about a living nature," but he believed that Americans for the most part had lost it. Wallace agreed. He believed that he and Roos shared Russell's conviction about what would be required to change such a deplorable spiritual situation. "All great spiritual movements," Russell insisted, "must have a life arising out of mother Earth."23

For Wallace, concerned as he was with the decline of the rural culture of his Iowa youth, involvement with the land, especially farming, was as much a spiritual endeavor as a practical one. It was a feeling that dated back to his childhood tutoring by the great botanist, George Washington Carver, a student of Wallace's father at Iowa State College. The young Henry A. had accompanied Carver on botanical field trips. From Carver, Wallace gained a sense that "God was in every plant and rock and tree" and that the farmer was "obligated ... to call on the God in whom he so deeply believed and felt as a creative force all around him." Wallace allowed that it was impossible to demonstrate scientifically the impact of spiritual beliefs on agriculture, but he felt sure that a true love for one's plants would yield a real result although it could "never be revealed in any statistical array of tables and cold figures. ${ }^{24}$

IF GOD or some spiritual essence was present in plants and in the land, then those closest to the land must be best suited to nurturing such powers. For Wallace, Charles Roos appeared to

23. HAW to Juanita Roos, 23 November 1931; Russell to HAW, 6 November 1931, Wallace Papers.

24. Henry A. Wallace and William L. Brown, Corn and Its Early Fathers (East Lansing, MI, 1956), 118-19. On Wallace's agreement with Carver's philosophy, see Schapsmeier and Schapsmeier, Henry A. Wallace, 18-19; Des Moines Register, 17 January 1943; and HAW to Carver, 22 October 1932, Wallace Papers. 
be just such an individual. Roos's affinity for the earth was strong and clear. And, like Wallace, his spiritualism was also tied to Theosophy. By the time Wallace met them, both Charles and Juanita were involved with a group known as The Society of The Temple of the People. Charles, in fact, had been associated with the temple for thirty-one years. ${ }^{25}$

Led by Dr. William H. Dower and Francia A. La Due, the temple was an offshoot of a Syracuse, New York, Theosophical Society lodge. In 1903 Dower and La Due led their followers to California and settled near the coast, north of Santa Barbara. Their community, Halcyon, was incorporated in 1905 as the Temple Home Association, a cooperative colony. The association existed to establish a community where the land would be owned collectively and where "Capital and Labor may meet on equal terms with no special privileges to either." 26

The temple's brand of Theosophy had a strong thread of Christianity running through it. A "message" from the "Great Master," first published in 1900 and sent in reprint form to Wallace, spoke of an apocalyptic strife, "Judas power," the "Christ in thine own soul," as well as gaining "freedom ... from the clutch of the Beast, the embodied Mammon." At the same time, Dower asserted that the temple was a "direct continuation" of Helena Blavatsky's enterprise. Other temple material explained to "neophyte disciples" that they would begin a process of examining their previous lives, referring to the central Theosophical principle of reincarnation. ${ }^{27}$

In November 1931 Wallace sent his six dollars annual dues to the temple and began correspondence lessons in its brand of Theosophy. Dower characterized him as a "very fine student" whose answers to the course questions indicated a "splendid

25. Juanita Roos to HAW, 22 October 1931; Charles Roos to HAW, [30 December 1931], Wallace Papers.

26. Campbell, Ancient Wisdom, 159. Campbell quoted an issue of the Temple Artisan, the Temple Home Association's magazine, as it was cited in Robert V. Hine, California's Utopian Colonies (San Marino, CA, 1953), 55.

27. "To My Beloved," reprinted from the Temple Artisan, June 1900; Form letter from Dower, 14 October 1931; "The Master's Touch," Temple Teachings, Open Series, No. 184, Wallace Papers. 
knowledge" of Theosophy's fundamentals. ${ }^{28}$ Dower also answered Wallace's questions about issues outside the immediate realm of Theosophy. When Wallace queried him, for instance, about the causes of the Great Depression, Dower responded in a manner that touched the very core of the issues that had been troubling Wallace for more than a decade. The depression, Dower wrote, made it clear that western civilization, "based on commercialism and the competitive system," and so caught up in modern technology, was "wrong at the root." Invoking a credo of the early American republic, he asserted that the only remedy was a "new Order of the Ages." The ability of the "Mammon forces" to so greatly skew the distribution of wealth proved, Dower concluded, that there were fundamental flaws in American society that could be ameliorated only by basic social, economic, and political change. Neither the invocation nor the conclusion were lost on Wallace. ${ }^{29}$

Wallace also seems to have been attracted by Dower's recollections of a close association with a Native American tribe. When Wallace wrote Dower of a trip that he and Roos were considering, during the summer of 1932, to a village of the Onondaga tribe near Syracuse, New York, Dower replied that when he had lived in Syracuse he had actually been "adopted" into the Onondaga tribe. He discussed his closest friends in the tribe, including one who was wise in Theosophical knowledge. Wallace apparently expressed to Dower his overwhelming desire to meet with this tribe, and later reported the powerful experience of the trip itself. Dower concluded that Wallace must have lived an earlier life with the Iroquois; his desire for contact obviously derived from "some cycle" in Wallace's life that was manifesting itself at that moment. ${ }^{30}$

For Wallace, Native American religion was important for more than personal reasons. When he first described Charles

28. HAW to Roos, 28 November 1931; Dower to HAW, 8 April 1932; Dower to Charles Roos, 1 June 1932; Dower to HAW, 28 October 1932, Wallace Papers.

29. Dower to HAW, 11 March 1932, Wallace Papers.

30. Dower to HAW, 1 July 1932; Dower to HAW, 9 September 1932; Charles Roos to HAW, [summer 1932?], Wallace Papers. 
Roos to George Russell, for example, he stressed Roos's belief "that there is a great need of some of the fundamental spirituality of the old Indian religions being introduced into our modern American attitude. ${ }^{\prime 31}$ By 1931 Wallace was thinking a lot about how he might help to fill the emptiness in American culture just as he pondered means to lessen America's social and economic ills. It was clear to him that as the world was collapsing economically in global depression, it was time for a "new religious longing" to appear if a "new order" were to issue from the "chaos." ${ }^{\prime 32}$ Just as he proved willing to experiment with social and economic policy as a member of Roosevelt's New Deal administration, Wallace was ready to experiment with possible remedies for the spiritual ailments of civilization.

SUCH CONCERNS help explain the best known and most controversial of Wallace's spiritual associations - that with the Russian emigré artist, poet, essayist, and Theosophical spiritualist Nicholas Roerich. ${ }^{33}$ Wallace apparently came into contact with Roerich around 1929-1930, at the time he was renewing his acquaintance with George Russell. Considering Wallace's interest in both Russell and Charles Roos, his attraction to Roerich's mystical writings makes sense. Perhaps better than any of Wallace's other spiritualist associates, Roerich wove together the different threads of Wallace's vision.

Roerich passionately advocated an eclectic pursuit of knowledge that must have touched Wallace profoundly. Roerich wrote of science and mysticism in similar terms, according each

31. HAW to Russell, 22 October 1931, Wallace Papers.

32. HAW to Dr. J. F. Corbett, 14 October 1931, Wallace Papers.

33. Wallace's connection with Roerich, especially as it was manifest in their correspondence - dubbed the "Guru Letters" - has been written about in detail many times. A brief treatment will thus suffice here. The two best discussions of the Wallace-Roerich relationship and the controversies that arose out of it are in Torbjorn Sirevag, The Eclipse of the New Deal and the Fall of VicePresident Wallace, 1944 (New York, 1985), 510-20; and Markowitz, People's Century, 333-42. J. Samuel Walker discussed Wallace's spiritualism and his association with Roerich in Henry A. Wallace and American Foreign Policy (Westport, CT, 1976), 50-60, although he was apparently unaware of the larger, primarily Theosophical context of Wallace's activities. 
its due as a source of life-enhancing wisdom. One never knew, Roerich wrote, where the "useful seed" of that wisdom might come from: "the physicist, bio-chemist, botanist, physician, priest or historian or philosopher or a Tibetan lama, or Brahminpandit, or Rabbi-kabbalist, or Confucian or an old medicine woman, ... who will make the most important contribution?" Roerich not only saw value in various forms of wisdom; he presented them in metaphors that would strongly attract an individual of Wallace's agricultural inclinations. Roerich wrote of the open-minded pursuit of knowledge - approaching the "realm of light" — as nurturing "the garden of Light." Creative thought, he insisted, like the "most delicate flowers . . . must be cultivated." ${ }^{34}$

In the 1920s and 1930s Roerich promoted an international treaty providing for the protection of the art treasures of all nations during wartime. The "Roerich Pact" became a reality in 1935, as a pan-American treaty protecting "artistic, religious and scientific institutions and historic monuments." Wallace, as a champion of the pact and a member of Franklin Roosevelt's cabinet, was the signatory for the United States. ${ }^{35}$

At about the same time, Wallace, as secretary of agriculture, commissioned Roerich to head up a Department of Agriculture expedition to Asia in search of drought-resistant grasses that might benefit the drought-ravaged American Midwest. Roerich was something of an expert on Asian culture, so he was at least an arguably valid choice to lead a scientific foray into that part of the world. Nevertheless, Roehrich's dubious political activities while in China ultimately led to the collapse of the expedition in an embarrassing international relations controversy. Wallace contributed to the controversy by first defending Roerich unquestioningly against various accusations of misconduct and then, later, completely disengaging from him when it became apparent that the accusations were accurate. ${ }^{36}$

34. Nicholas Roerich, Realm of Light (New York, 1931), 4-5, 18-20.

35. Washington Post, 16 April 1935.

36. Markowitz, People's Century, 336-38; Sirevag, Eclipse of the New Deal, 512-13. 
Wallace's relationship with Roerich, especially its spiritual aspects, became an issue more than a decade later, during the presidential campaign of 1948. Then their association was brought to light by the conservative newspaper columnist Westbrook Pegler, who smeared Wallace by publishing and critically interpreting several letters Wallace had written to Roerich and Roerich's secretary. Pegler harped on selected aspects of the correspondence, some of which may have been faked, in such a way as to make it seem that Wallace had been under the mystical sway of Roerich, with Roerich portrayed as Wallace's "guru. ${ }^{\text {" }}$ 7

The vast majority of the more than 150 letters consisted of Wallace's comments, couched in spiritualistic language, on various policy issues in which he and Roerich shared an interest. Topics included U.S.-Japanese and U.S.-Soviet relations, the Roerich Pact, Roerich's museum in New York City, and the Department of Agriculture expedition that Roerich led to China. Wallace brought a Theosophical perspective to the descriptions he made to Roerich of his daily struggles in government. In 1933 , for instance, Wallace presented a poignantly spiritualistic view of the different forces pulling at Roosevelt as he was deciding whether or not to recognize the Soviet Union, a policy Wallace opposed. Implying that Roerich's anti-Soviet sentiments may have influenced his own stance on recognition, Wallace declared that in "these days of fiery trouble ... the indications of Morya through Modra [Theosophical names for Roerich and an intermediary] have governed under the most difficult circumstances." The problem, Wallace explained, was that many individuals around the "One toward whom my efforts have been addressed" (Roosevelt) were "loyal to his personality but false to his ideals." Depicting Roosevelt's nature in spiritual terms, Wallace noted that "The One" had a "lovely, upwardsurging spirit with a certain appreciation of what he calls

37. The Pegler columns appeared daily in the Los Angeles Examiner, among other places, March 9-12, 1948. The Roerich connection also underpinned Dwight MacDonald's central image of Wallace as a "fuzzy-minded" mystic. In fact, some the letters did begin with "Dear Guru," which is the origin of their collective sobriquet, the "Guru Letters." 
'hunches.'" This characteristic combined with a "charming open mindedness" to render Roosevelt manipulable by "designing people," including not only other members of the administration, but also the "tigers," a code name for the Soviets. Wallace thus felt compelled to discuss the matter of recognition with both FDR and Secretary of State Cordell Hull "in the most emphatic terms." ${ }^{\prime 38}$

Even though the substance of most of the letters was essentially political, they also reveal the nature of Wallace's spiritualism, as well as the way it informed his social and political visions. In one instance, Wallace exhibited his affinity for Native American spiritualism, stating that the "earth beat, the Indian rythm [sic] of Ancient America haunts me like a faint fragrance from the past while I strive to center my complete forces on the pressing problems of the day." As he strove to find meaning in the human condition, Wallace mixed imagery from a variety of sources. In the course of asking Roerich "what structure of government" the United States was moving toward, he drew on the Hebrew Scriptures to compare himself to "a young Saul or David to whom a Samuel had appeared. But instead of oil there is musk and rose from the sacred heights ... as I . . think of the crystal soul behind the living eyes above the cleft of beard." On another occasion Wallace articulated both his strong sense of the spiritual, as well as his belief that he was somehow excluded from it by his duties in public life. He pointed out that he had long been aware of the "occasional fragrance from that other world which is the real world," yet he believed that for the time being he "must live in the outer world" while preparing himself for a more spiritual future. Wallace was even capable of mixing the symbols of Masonry and the legends of King Arthur with Theosophy. Shortly before taking office as secretary of agriculture, he insisted to Roerich that "the Search, whether it be for the Lost Word of Masonry or the Holy Chalice or the potentialities of the age to come, - is the one supremely worth while objective. All else is karmic duty. Here is life. But

38. HAW to Roerich, 29 October 1933, item 121; fragmentary note in Wallace's handwriting, item 80, "Guru Letters" folder, box 9, Samuel Rosenman Collection, Franklin D. Roosevelt Library, Hyde Park, NY. 
surely every one is a potential Galahad, a Parsifal incurring the utmost peril insofar as his energy is in this search in terms of the outer world." Suggesting the spirit in which he viewed the coming political struggles, Wallace claimed the "seat perilousin letters of fire-for the one who has won the right to come by using the inner principles to conquer in the outer world." "What challenge!" he exulted. "What adventure! What patience and grief!"39

Although a distinct minority in the body of correspondence, Wallace occasionally wrote letters to Roerich that were wholly spiritualistic in character and content, replete with images and terms drawn from Theosophy as well as Roerich's art and writings. One that actually began with the greeting "Dear Guru" stated that the "rosy Himalya [sic] painting brought delight to my wife. And for a brief moment ... I thought I preferred it" to the real sun. The "brooding" nature of Roerich's painting, Wallace explained, was something "very close and personal to me-brooding in the predestined spot-so it is in the dream of my heart. Brooding at the close of Kali Yuga on the portents of the days to come. And the rosy glow of the other [the actual sun] is suggestive of the glory of the days to come." Wallace closed the letter by hoping that "In humility and daring, with insight and continual striving may I join in the service to Shamballa." 40

Ever since Westbrook Pegler called attention to the letters in 1948, discussion of the Wallace-Roerich connection has focused largely on whether or not Wallace actually wrote the letters, the subtext being that if he had written them it would be proof of his alleged "fuzzy-mindedness." 41 In fact, it is

39. HAW to Madam and Professor Roerich, 1 September 1933, item 148; HAW to "M" (a code for Roerich), n.d., item 130; HAW to "Prof. R.," n.d., item 103; HAW to "M," January 1933 (?), item 53, "Guru Letters."

40. HAW to "Guru," 17 April 1934, item 108, "Guru Letters."

41. The authenticity of many of the letters has long been called into question. See Markowitz, People's Century, 338-39, 342. Bruce M. Swain, "Henry A. Wallace and the 'Guru Letters': A Case of Successful Stonewalling," MidAmerica 69 (1987), 5-19, analyzes the "Guru Letters" as an example of the ability of a political figure to evade public discussion of a potentially damaging personal disclosure. 
almost certain that Wallace did write many if not all of the more than 150 items that make up the collection. Names familiar from Wallace's other correspondence-including those of Dower and Roos-appear in several of the so-called Guru Letters. Those names probably would not have been known collectively to any of Wallace's contemporaries, save those few with an extremely intimate knowledge of his affairs. ${ }^{42}$ Many of the other terms Wallace used in the letters, such as the "masters," the "land of the masters," and the "light," as well as various sobriquets - the "One" and the "Flaming One" for President Roosevelt, or the "Sour One" for Cordell Hull-are similar to terms found in the writings of Russell, Dower, and Roerich. ${ }^{43}$ Even in his occasional use of the word guru it seems likely that Wallace was simply minding his jargon, as any careful scientist would. Roerich himself defined a guru as nothing more than an "experienced preceptor." ${ }^{\prime 44}$ Considering Roerich's experience in spiritual and Theosophical matters, characterizing him as guru would have been for Wallace, the diligent student, an appropriate choice for a term of endearment.

In the end, debating the authenticity of the Guru Letters makes sense only if the letters are considered aberrant. For individuals such as Westbrook Pegler, the letters, if real, would stand as proof that Wallace was "off-center mentally" and thus not fit to (potentially) lead the nation. ${ }^{45}$ But in light of Wallace's mystical explorations of the 1920s and 1930s, the content of the Guru Letters hardly appears extraordinary. Wallace's involvement with Roerich arose out of his ongoing spiritual studies; it was just one manifestation of his openness to any form of knowledge that might fill the spiritual vacuum he per-

42. Items 2, 4, 5, "Guru Letters."

43. There is a two-page "code word sheet" in the "Guru Letters" folder indicating to whom the various sobriquets found in the letters applied.

44. Roerich, Realm of Light, 13.

45. Los Angeles Examiner, 9 March 1948. Pegler actually supported a private investigation into the authenticity of the Guru Letters in 1948. See the Westbrook Pegler Papers at the Herbert Hoover Presidential Library, boxes 107 and 108. One imagines Pegler and those who thought like him fairly bursting with indignation if they had had knowledge of the actual scope of Wallace's spiritual endeavors in the late twenties and early thirties. 
ceived in modern society. Norman Markowitz came to a similar conclusion, suggesting that Wallace's controversial letters to Roerich were simply "another expression of his lifelong search to find a grand mechanism" to "reconcile order with freedom and science with religion." 46

WALLACE'S QUEST for a spiritual balm for America led him into one other relationship during these years. It is not clear whether Wallace met L. Edward Johndro through Charles Roos or on his own, but by the middle of 1932 both the Rooses and Wallace had come to have serious regard for Johndro's judgment. By the time Wallace came into contact with him, Johndro, an astrologer who lived in Oceanside, California, had developed a theory that posited the existence of cosmic electromagnetic energy waves that controlled earthly events and cycles, including "price values, crops, weather, or psychological trends." Tying together several of Wallace's interests, Johndro argued for something of a spiritualistic unified field theory: that once this cosmic energy was "recognised it ought to be clear to all that all terrestrial phenomena . . . are EQUALLY EFFECTS of this law of invisible force." This meant, for Johndro, that the usual sorts of statistical analyses, especially those of economists studying business cycles, were wholly mistaken in their interpretations. ${ }^{47}$ For a decade, Wallace had watched predictions of economic recovery based on business cycles come to nothing, first in the case of agriculture, and, after 1929, for the rest of American society. Now skeptical of such prognostications, he concluded that perhaps Johndro was correct. By the middle of 1931 Wallace acknowledged that he was "becoming increasingly

46. Markowitz, People's Century, 341.

47. L. Edward Johndro to HAW, 16 January 1931, Wallace Papers (his emphasis). Numerous remarks in a series of letters between Wallace and Johndro suggest that this letter was misdated by Johndro, and was actually written and sent in January 1932. See HAW to Johndro, 5 January 1932; HAW to Doherty Publishing Co., 17 September 1931, Wallace Papers. For a more detailed understanding of Johndro's thinking, see L. Edward Johndro, The Earth in the Heavens: Ruling Degrees of Cities, How to Find Them (1929; reprint, New York, 1973); and idem, The Stars: How and Where They Influence (San Bernardino, CA, 1929). 
suspicious of strict cyclical" reasoning. ${ }^{48}$ The following year, despite his doubts about astrology, he began to listen to Johndro's astrological counsel.

In 1932 the Wallace family lost Wallaces' Farmer to the vicissitudes of the Great Depression. A year earlier Wallace had informed Johndro that if such an event were to occur, he might run for the United States Senate from Iowa as a Democrat. Acknowledging that Iowa farmers remained staunchly Republican, Wallace speculated that such a campaign might "break the link which holds me to Iowa agriculture." Allowing that he still had his corn business to fall back on if all else failed, Wallace was implicitly asking for Johndro's assessment of a possible political career if he were to leave publishing. Johndro responded with a detailed astrological analysis of the incumbent, Republican Senator Smith W. Brookhart, concluding that Brookhart was likely to win even though Wallace's horoscope made him the "natural opponent" for the Democrats to put forward. ${ }^{49}$

Charles Roos was all for Wallace's entry into American politics. He believed that Wallace should enter the United States Senate as a Democrat and then return to Iowa as its governor. Even after he had conceded that Johndro's prediction of defeat might be accurate, Roos still thought that Wallace should opt for the senatorial campaign. Although Wallace might lose the election, Roos argued, the "'publicity' will be Big Medicine for other things the Gods have in store for you." A loss, if it did occur, would not hurt Wallace, and would in fact garner him much notoriety and support. ${ }^{50}$

Wallace hesitated to embark on a career in national politics. He pointed out to Roos that he was considering staying with Wallaces' Farmer as editor for a few more years and then pursuing his corn studies full time. That course would allow Wallace to devote much of his time to endeavors in which the two of them could collaborate. Wallace feared that a successful run for the Senate might prevent a "peaceful exit" from his

48. HAW to Louis H. Bean, 23 July 1931, Wallace Papers.

49. HAW to Johndro, 19 January 1931; Johndro to HAW, 21 January 1932, Wallace Papers.

50. Roos to HAW, 18 February 1932, Wallace Papers. 
current life to one that he hoped for, centered on the "Inner Life." ${ }^{51}$

For Wallace, a political career was only one possible means to a much more important end: to find an appropriate way to address the spiritual weakness he discerned in an economically and socially afflicted modern America. In two revealing letters, written two days apart in October 1931, Wallace asked Johndro how he might work for that "cause." Because Charles Roos's spiritualism combined many of the features he deemed vital, Wallace asked Johndro if he could determine astrologically whether Roos and Wallace could benefit each other and, jointly, "the cause." Wallace believed that both he and Roos were inclined toward working out the "spiritual foundations" for a "true creative (religious, if you please) expression for the American people. ${ }^{\prime 52}$ Several months before he queried Johndro about the possibility of entering the 1932 race for the Senate, Wallace explained that he was at heart "neither a corn breeder nor an editor." He felt himself rather to be a "searcher for methods of bringing the 'Inner light' to outward manifestation and raising outward manifestation to the Inner light." "Most important," Wallace asserted, "I shall be seeking an opportunity to find the religious key note of the new age." If working with Roos was not the way to go about this, then perhaps he ought to make his spiritual connection through Dower's temple or some other Theosophical group, or perhaps with Johndro himself. Even in the intensity of his search, Wallace realized that he had to answer this question himself. He suggested that Johndro disregard it, that it "merely illustrates the state of my mind." ${ }^{15}$

51. HAW to Charles Roos, 22 January 1932; HAW to Charles Roos, [ 4 February 1932], Wallace Papers.

52. HAW to Johndro, 22 October 1931, Wallace Papers.

53. HAW to Johndro, 24 October 1931, Wallace Papers (his emphasis). A possible alternative Theosophical group mentioned by Wallace was the Besant Theosophical Society, named for Annie Besant, rival of William Quan Judge in the early Theosophical Society schism. Since Wallace saw Dower as following in Judge's path, Wallace's familiarity with the Besant society indicates that Wallace had investigated other strains of Theosophy in the course of his spiritual quest. For evidence of Wallace's connection with the Besant society as well as other groups, see Wallace Papers, boxes 61 and 63 . 
In response to Wallace's ambiguous requests for guidance, Johndro suggested that Wallace follow his "own light, none other." Johndro believed that if Wallace were unsure about accepting, absolutely, the leadership of any particular individual, then perhaps he no longer needed a mentor at all. ${ }^{54}$ Nevertheless, Wallace did request from Johndro assessments of both Herbert Hoover and Franklin D. Roosevelt. After receiving them, he informed Johndro that he would meet with Roosevelt. How much astrological analysis affected Wallace's decision to join Roosevelt's cabinet, if it did at all, is not known.

In the course of his correspondence with Johndro, Wallace characteristically began the task of studying Johndro's system, just as he was working to master the Theosophical lessons sent to him by Dower's Temple of the People. He quickly became adept at Johndro's methods, in part due no doubt to his prior studies of planetary alignments and weather patterns. ${ }^{55}$

Wallace's "prolonged observation and contemplation" of these varied theories of knowledge led to a significant "crystallization of thought." He decided that Johndro's astrology was an aspect of a more transcendent science. At the same time, he concluded that much of mainstream science was encumbered by "superstition of its own." ${ }^{156}$ From his concurrent pursuit of scientific and spiritual knowledge, Wallace realized that his corn genetics, his weather and planetary alignment correlations, and his statistical studies ultimately were no more valid as paths to knowledge than the work he undertook with his various spiritualist colleagues and mentors.

More important, Wallace hoped that in some combination these diverse ways of seeking knowledge would yield solutions to the overwhelming problems now facing civilization. Even as his family was losing ownership of the newspaper that had been at the center of its collective life for almost four decades, Wallace did not lose his passion for this search. In April 1932,

54. Johndro to HAW, 16 January 1931 [or 1932?]; Johndro to HAW, [early 1932], Wallace Papers.

55. See HAW to Juanita Roos, 20 February 1932; HAW to Johndro, 24 February 1932; and HAW to Johndro, 10 March 1932, Wallace Papers.

56. HAW to Johndro, 10 March 1932, Wallace Papers. 
as he reflected on the loss of Wallaces' Farmer, he wrote to Roos that the "zest of life is with me." Wallace suggested that modern civilization would most likely deteriorate before it improved, yet he still insisted that it was "an honor to be alive in these days." ${ }^{\prime 57}$

AFTER THE SUMMER OF 1932, Wallace did not press the perspective he had gained from his Theosophical and related spiritual studies, either in his editorials while still in Iowa, or in his public activities after becoming secretary of agriculture. At least he did not press it in anything approaching an explicit sense. His reticence may have been due in part to an unfortunate if minor furor he experienced early in 1932 after giving a speech to a group of ministers in Des Moines. In the speech Wallace allegedly claimed that the dilemmas facing society indicated that the world was in need of a "new religion." Wallace received strong criticism from individuals who read questionable newspaper accounts of the talk, as well as from at least one Iowa clergyman who was not actually present when Wallace spoke. In the end the incident appears to have resulted from a multiplication of misperceptions rather than from any especially outlandish remark on Wallace's part. But the incident's brief intensity may very well have impressed on Wallace the unfriendly reception his non-Judeo-Christian beliefs would likely receive if he presented them publicly. ${ }^{58}$

It is not clear to what extent Wallace continued his private spiritual studies during his years of public service from 1933 to 1948. What is clear is that by the time he left Iowa to take up national office in 1933, his spiritual experimentation had covered a wide range of philosophies and had attained a fairly high level of sophistication. Decades before the spiritual renaissance of the 1960 s and the advent of the "New Age" movement of the 1980s, Wallace addressed the spiritual disaffection that he and many

57. HAW to Charles Roos, 7 April 1932, Wallace Papers.

58. See E. T. Gilbert to HAW, 19 January 1932; HAW to Rev. John Todd, 19 January 1932; Todd to HAW, 20 January 1932; HAW to Todd, 21 January 1932, Wallace Papers. 
others saw as the great dilemma of urban-industrial civilization. Wallace searched for the means that would enable himself and other Americans to adjust emotionally and psychically to the disorienting changes of the previous seventy-five years. And he did so in a manner that uniquely combined the two sides of his intellect. From a modern perspective, science and spiritualism seemed wholly incompatible. Indeed, the distinctions between them formed a rough analog for the tensions in early twentiethcentury American culture between the traditions of the preindustrial past and the scientific outlook of industrial civilization. But whether or not the spiritualistic component of Wallace's outlook appears incongruent with his science, it is clear that Wallace did not come by it lightly. It arose rather from the disciplined explorations of a scientist into the circumstances of the modern human condition. 
Copyright of Annals of Iowa is the property of State of Iowa, by \& through the State Historical Society of Iowa and its content may not be copied or emailed to multiple sites or posted to a listserv without the copyright holder's express written permission. However, users may print, download, or email articles for individual use. 